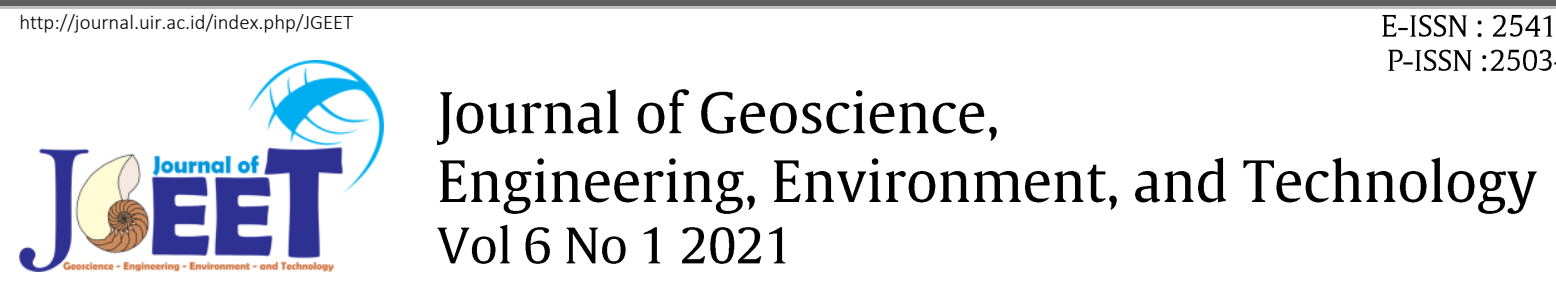

RESEARCH ARTICLE

\title{
Microscopy Observation of Samosir Formation Paleosoil, Tuktuk Sidaong, North Sumatera, Indonesia.
}

\author{
Danni Gathot Harbowo ${ }^{1}$ and Siti Zahra ${ }^{1}$ \\ ${ }^{1}$ Geological Department, Institut Teknologi Sumatera, Jatiagung, Lampung, Indonesia.
}

* Corresponding author : danni.gathot@gl.itera.ac.id

Tel.:+62-852 94685303

Received: Jun 30, 2020; Accepted: March 17, 2021.

DOI: 10.25299/jgeet.2021.6.1.5217

\begin{abstract}
Samosir is the islands that emerge and standing upon on Toba Caldera after it's the last eruption at 74.000 years ago. Samosir Island known as the caldera floor that uplifts parallel with Toba's caldera flooding. In this study, we have observed an outcrop in Tumutuk, Samosir Island that hypothesized as a lacustrine deposit, and we found a paleosoil layer that might give more answers about the geological process in this area at the past time. Based on this outcrop, we described it, followed to measure its stratigraphy section, and took representative samples from the paleosoil layer, then observed the samples under the stereo-microscope as polish rock section, in normal light \& negative images. As the result we identify several features of paleosoil \& its sedimentary grain that shown this paleosoil layer, two events of the volcanoclastic deposits flown, and exposed two-time, and forming soil, it may form in the shallow swamp in a lacustrine environment, coincide with caldera flooding and caldera floor uplift event.
\end{abstract}

Keywords: Paleosoil,Toba Caldera,Samosir Island.

\section{Introduction}

Paleosoil is known as soil that formed in a landscape and preserved well by buried by other younger sediment in geologic time, as the past as well lithified become a rock. In commonly, it uses to interpret a moment in the past time, on its layer, that had been exposed to the surface and interacts with atmosphere before it eroded or buried after that (Nemecz \& Hartyáni, 1995; Nettleton et al., 2001), including buried by volcanoclastic sediment (Ugolini \& Dahlgren, 2002). Paleosoil can observe under stereo microscopy to gain more details of descriptive informations. It's very important to understand the presence of these layers in the an outcrop to reconstruct the paleoenvironment and the geological event, that may give more information in the past time (Driese et al., 2016; Tabor \& Myers, 2015).

In this study, we observed the presence of paleosoil in one of outcrop in Samosir Island, in Toba Caldera area (see Figure 1). It might be connected with the last ancient eruption that happened in Toba Volcano Complex in around 74.000 years ago.

Several researchers had proposed that Samosir Island is a Toba Caldera floor that uplifts at the time by time after its last eruption (Aldiss \& Ghazali, 1984; Chesner, 2012; Ninkovich, et al, 1978). Besides that,
Toba Caldera was flooded by atmospheric water since rains drown the caldera floor and form a layer of soil which its form as Samosir Formation (Solada, 2018; Timmreck, et al, 2012). So in this paper, we proposed to gain more information about the evidence of that geological process by observing its paleosoil layer under the stereo-microscope describe the paleosoil features \& pedoturbation.

\section{Materials \& Methods}

Based on the outcrop that we found in Tuktuk Sidaong (N: 2.659126; E: 98.850417), the part of Samosir Formation. We have ob-served its geological outcrop by describing the rock layers by the stratigraphical meas-ured section. We also describe the rock grain size, the sedimentary structure that might occur, basal boundary upon each layer, and took several representative rock samples, and labeled. Before the rock sam-ple prepares for microscopy observation, we also reacted to the rock sample with 1 $\mathrm{N}$ Hydrochloric acid $(\mathrm{HCl})$ to identify the presence of carbonate minerals on rock samples (such as the calcite or aragonite minerals) because it's very important for depositional environment interpretation. 


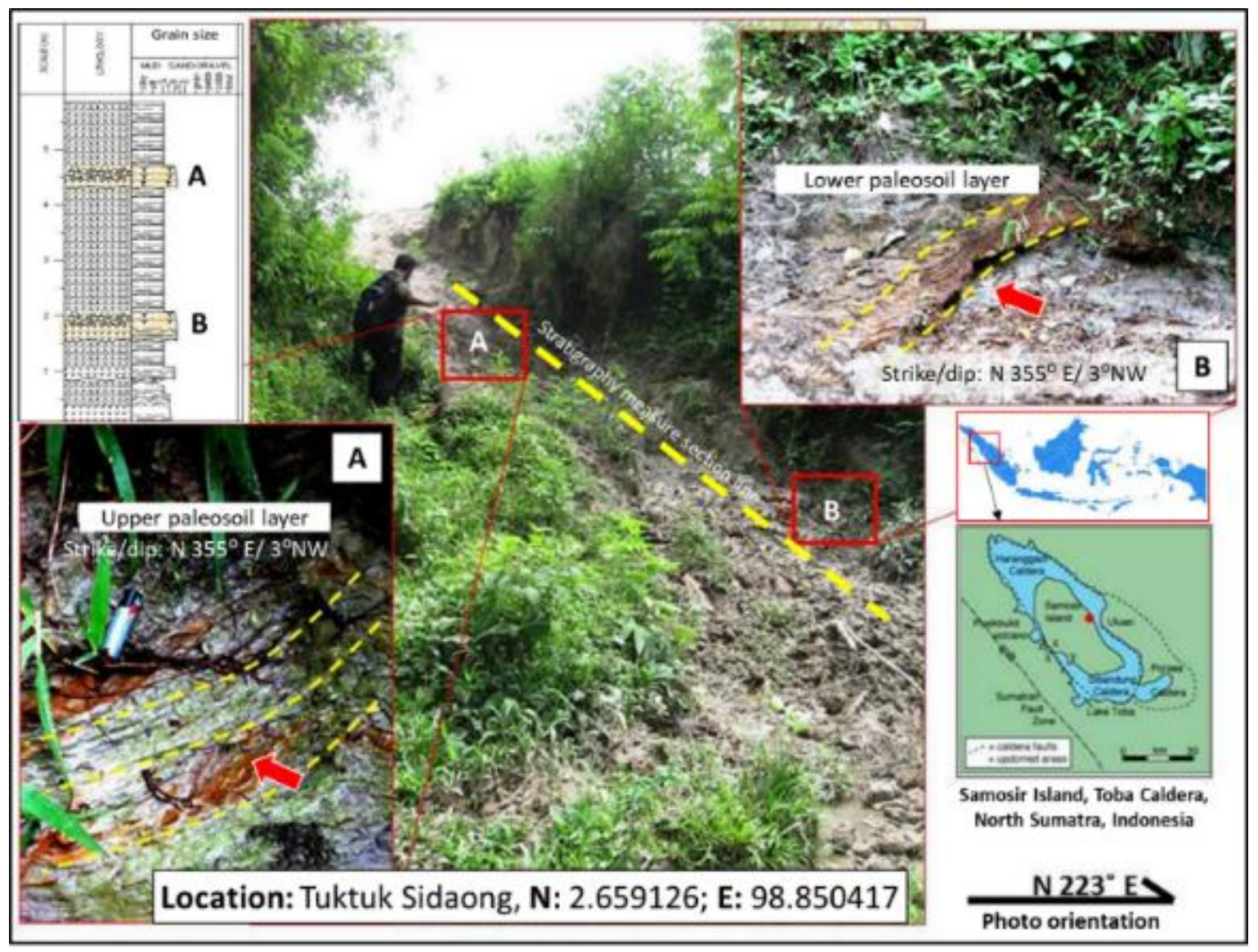

Fig 1. Observed paleosoil outcrop location \& the section line that measured in this study.

Then the paleosoil rock samples were prepared by horizonation, (3) redox condition, (4) accumulation of polish it gently and avoid from the other rock sample soluble minerals, (5) illuviation of insoluble contaminations. Make sure the rock samples are dry mineral/compound, (6) in situ mineral alteration. The enough while it proceeds. After it polished, epoxy also result of images of the result shown in Figure 2 and dropped upon the surface of rock samples to make Figure 3.

more clearance visualization under a stereo- We have identified the presence of paleomicroscope. Besides its observer in normal light, we pedoturbation in rock samples in 20x magnification. also take an image of the samples in the negative Paleo-pedoturbation defines as the mark of the past image to reconfirm a paleosoil feature \& pedology phenomena that occur and preserved well in pedoturbation more contrast as well. pale-osoil, such as the presence of mud-cracks

\section{Result \& Discussion}

Based on the measurement of the stratigraphical section of the observed outcrop, we have defined that at least there are two main layers of paleosoil, i.e, the upper layer (thickness: $31 \mathrm{~cm}$; strike/dip: N $355^{\circ} \mathrm{E} /$ $3^{0} \mathrm{NW}$ ) as younger paleosoil layer (mark as "Layer A") and the lower layer (thickness: $47 \mathrm{~cm}$, strike/dip: Strike/dip: N $355^{\circ}$ E/ $3^{\circ} \mathrm{NW}$ ) as older paleosoil layer (mark as "Layer B"). Both of these layers were separated by $430 \mathrm{~cm}$ thickness of fine-grain volcanoclastic layers. The upper layer $(\mathrm{A})$ had more finely grain size (around $0.031-0.0039 \mathrm{~mm} /$ clay to silt) than the grain size of the lower layer (B) which had fine to medium sand grain size, around $0.25-0.0625 \mathrm{~mm}$ (for detail see Figure 1).

For microscopy observation and describing of the paleosoil rock samples, we referred to Imbellon, 2011; Mack et al., 1993; Nettleton et al., 2001. Some aspects need to mention on paleosoil rock samples observation, i.e. (1) organic matter content, (2) pattern, the root-mark, or the remain of terrestrial infaunal activity.

On the upper-layer (A), we notice the presence of weathered biotite mineral as soil secondary forming (which appears as greenish color) which came from volcanic ash/clay as parent material (Figure 1, a1). It was one of the mechanisms of clay mineral forming after dissolved from a particular of volcanic minerals that carried below by surface water (or by surface flooding) in oxide condition. In the negative image, biotite mineral will appear brighter with a reddish color. Although with that, we also identify paleopedoturbation as the angular mud-crack pattern (Figure 1, a2). It looks like a rounded volcanic pumiceous clay (which appears as greenish-gray color) that coated by oxidized iron (appears in darkbrownish color). The presence of mud-crack patterns in paleosoil can be interpreted as dried a layer of mud, which at the beginning had been saturated by water content then followed by highly intense evaporation. 
This paleosoil layer was classifies as argisol-protosol of root-mark patterns (Figure 1, b1 \& b2). We identify (after Imbellon, 2011). there are $2^{\text {nd }}$ until $3^{\text {rd }}$ order of branch of a lateral

However, at lower paleosoil layer (B) we notice the rootfrom the main rootlet. The rootlet would have other type of paleo-pedoturbation, which is the kind some branch as root hair, which can definite as order.
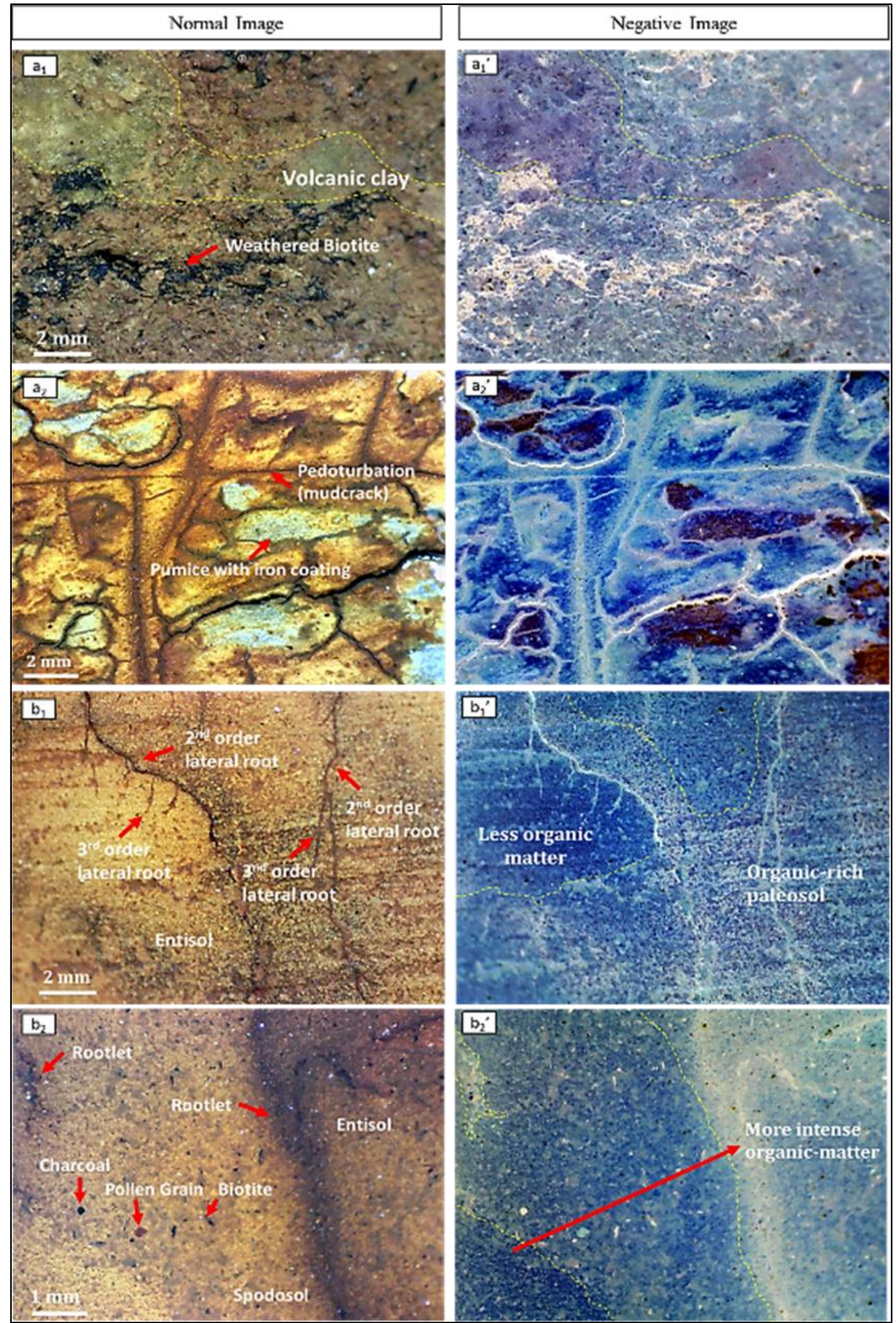

Fig 2. Normal Photo \& negative image of microscopy observation in 20x magnification, shown polished rock specimen of the upper paleosoil layer $\left(\mathbf{a}_{1} \& \mathbf{a}_{2}\right)$ and the lower paleosoil layer $\left(\mathbf{b}_{1} \& \mathbf{b}_{2}\right)$. There are several pedoturbations and other features were have identified. 

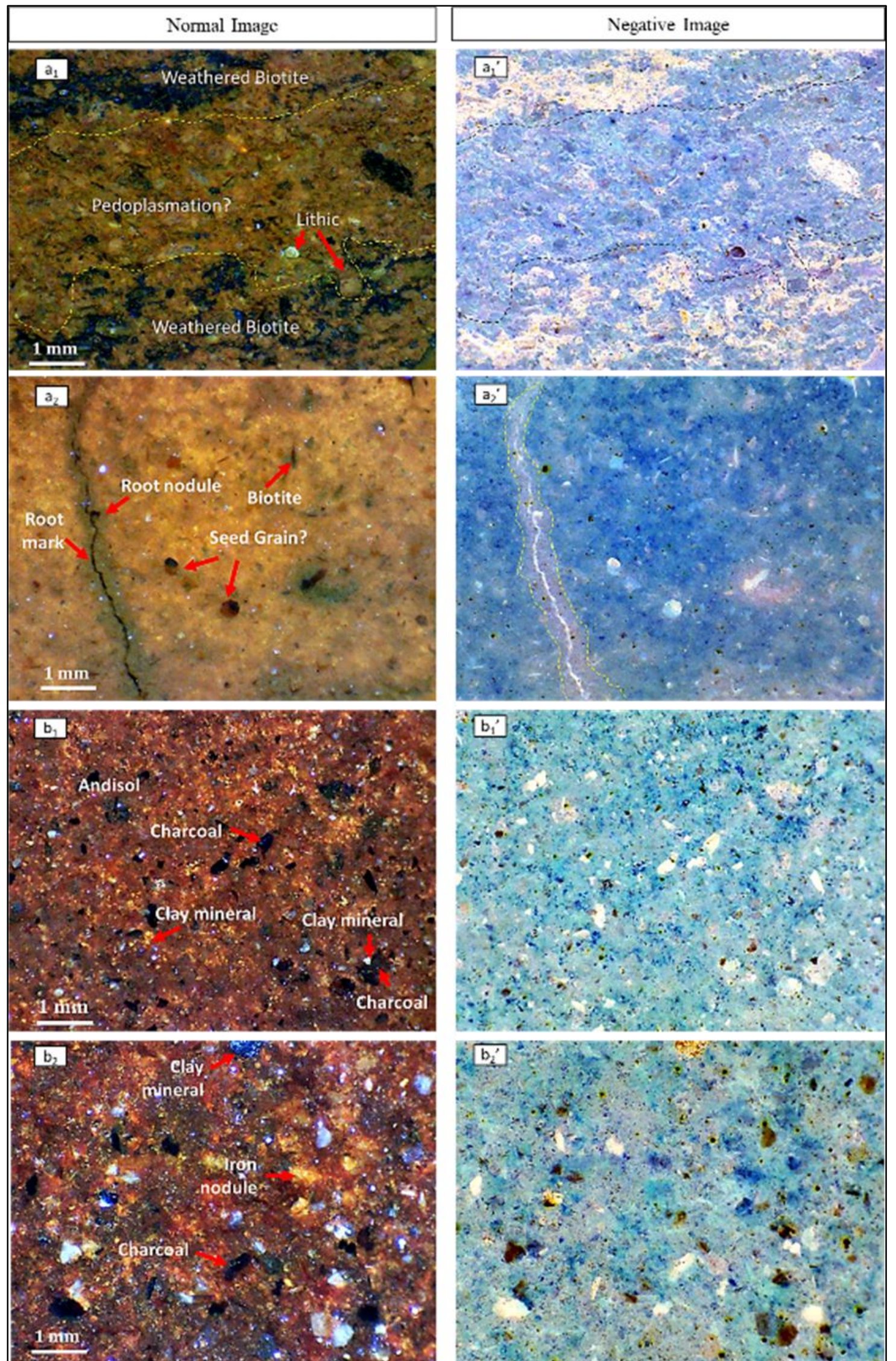

Fig 3. Normal photo \& negative image of microscopy polished rock section samples observation of upper paleosoil layer $\left(\mathbf{a}_{1} \& \mathbf{a}_{2}\right)$ and lower paleosoil layer $\left(\mathbf{b}_{1} \& \mathbf{b}_{2}\right)$ in $40 \mathrm{x}$ magnification shown the fragment and mineral grain, and other paleosoil features. 
Root activity triggered soil formation faster, it also from up-per sediments, permineralization, and promotes symbiosiswith soil microorganism to mineral replacement. This process plays a role in breakdown an insoluble mineral to more soluble unconsolidated soil/sediment turn into rock mineral form. Somehow it can support more biological (lithification).

activity \& develop more organic accumulation in soil, In the 40x magnification rock sample of Layer A, especially in the surrounding of rootlet (Laliberté et we also have described the grains and the al., 2013). That particular mechanism occurs in Layer microfragments (see Figure 2). On the Layer A B. Based on the morphology of the rootlet, this paleo- commonly finds weathered biotite with other granule pedoturbation represents as grass-like rootlet. In the lithic fragments in the same lamination. This same figure, we also noticed the grain of charcoal, lamination parallel with the lamination fragments of biotite, and a kind of palynomorph. By pedoplasmation as groundmass of clay grain size.

the whole of the description, it represents that this Pedoplasmation is the phase of the primary soilpaleosoil layer in the past time was a vegetated soil forming process which is a trans-formation of which mixing up with other sediment supply. Based weathered rock became into the part of soil horizons. on the presence of pedoturbation and the richness of This process leads the grain size of the parent rock mineral, this paleosoil classifies as vertisol/entisol to minerals to become finer than before. Biotite is a spodosol (after Imbellon, 2011). common mineral that can be found in volcanoclastic

At least, two mechanisms have a role in the material (Stoops, G., \& Schaefer, 2018). The biotite paleosoil-forming process, i.e. the primary and which was found in samples mixed up with other secondary processes. The primary process is the soil- oxidized iron minerals then weathered turned into forming process before preserved or known as clay minerals. The richness of clay mineral would pedogenesis. Meanwhile, the secondary process is all indicate the maturity of the soil-forming process. In kinds of processes that occur to the soil after it pre- the negative image, the weathered biotite would look served. There are 3 majors of rock weathering that brighter and appears more reddish (see Figure 2, a1). might occur, i.e physical, chemical, and biological In the same layer, we also found a root-mark with root weathering process (Hoosbeek and Bryant, 1992). All nodule. This nodule probably was a symbiosis beof them are directly involved in soil formation. The tween plant and the soil-bacteria which interact in the rock weathering could be noticed from the presence of root. Otherwise, we also notice palinomorf/seed like pedoturbation, such as root-mark, mud-crack, and also can find in these samples, it's shown that the liesegang-mark that preserve naturally. For the vegetation on in this soil was grown. secondary process, these occur along with overburden

Table 1. Recapitulation of microscopy description of paleosoil samples of upper layer paleosoil and lower layer paleosoil to resume for its past deposisitonal environment.

\begin{tabular}{|c|c|c|c|}
\hline \multirow{3}{*}{$\begin{array}{l}\text { Stratigraphic } \\
\text { measurement }\end{array}$} & Layer Code & A - upper layer paleosoil & B - lower layer paleosoil \\
\hline & Age Relative & Younger & Older \\
\hline & Thickness & $31 \mathrm{~cm}$ & $47 \mathrm{~cm}$ \\
\hline \multirow{8}{*}{$\begin{array}{l}\text { Specimen } \\
\text { description }\end{array}$} & $\begin{array}{l}\text { Grain size (mm) } \\
\text { (Wentworth Scale) }\end{array}$ & $\begin{array}{l}0.031-0.0039 \mathrm{~mm} \\
\text { silt - clay }\end{array}$ & $\begin{array}{l}0.25-0.0625 \mathrm{~mm} \\
\text { medium - fine sand }\end{array}$ \\
\hline & Organic matter content & less content (as seed-like grain) & rich content (as charcoal) \\
\hline & Horizonation, & $\begin{array}{l}\text { Mud crack, as vertical } \\
\text { pedoplasmation, \& less present of } \\
\text { fine root hair }\end{array}$ & $\begin{array}{l}\text { more complete pedoturbation as } \\
\text { rootmark (2nd - 3rd order lateral } \\
\text { root) }\end{array}$ \\
\hline & Redox condition, & less intense. & $\begin{array}{l}\text { more intense (present of darker } \\
\text { iron oxide) }\end{array}$ \\
\hline & $\begin{array}{l}\text { Accumulation of soluble } \\
\text { minerals }\left(\mathrm{CaCO}_{3}\right)\end{array}$ & absent, not react to $\mathrm{HCl}$ & absent, not react to $\mathrm{HCl}$ \\
\hline & $\begin{array}{l}\text { Illuviation of insoluble } \\
\text { mineral/compound }\end{array}$ & dominant present of biotite & $\begin{array}{l}\text { dominant with fine } \\
\text { volcanoclastic\& glass }\end{array}$ \\
\hline & Insitu mineral alteration. & $\begin{array}{l}\text { Weathered biotite mineral \& clay } \\
\text { mineral }\end{array}$ & $\begin{array}{l}\text { dominance the present of clay } \\
\text { mineral }\end{array}$ \\
\hline & Classification & Argisol - Protosol & Histosol - Spodosol \\
\hline \multirow[b]{2}{*}{ Interpretation } & Parent Material & Volcanic ash & Coarser Volcanoclastic \\
\hline & $\begin{array}{l}\text { Depositional } \\
\text { Environment }\end{array}$ & $\begin{array}{l}\text { freshwater swampy unfertile soil } \\
\text { arid-anoxic hypolimnium }\end{array}$ & $\begin{array}{l}\text { shallow lacustrine transition } \\
\text { oxicepilimnion }\end{array}$ \\
\hline
\end{tabular}


Then, in the lower layer (B) in 40x magnification, we observe the presence of sand size grain features. Many mineral grains found along beside the presence of charcoal and iron oxide nodule (See Figure 2, b1 \& b2). The majority of the minerals are classified as the clay-mineral group. Charcoal is carbonaceous fragments that mostly contained carbon formed from carbonizing of the plant tissue. The clay minerals are defines as hydrous aluminium phyllosilicates, sometimes with variable amounts of iron, magnesium, alkali metals, alkaline soil, and other cations. Clay minerals typically form over long periods as a result of the gradual chemical weathering of rocks (especially volcanoclastic rock), by low concentrations of carbonic acid and other diluted solvents (Dahlgren, et al, 1993). Based on all of the descriptions of this microscopy observation, we resumed and interpreted the geological process that occurs in the past time (for detail see Table 1 ).

Based on the superposition concept, the B layer was relatively older than layer $A$. The volcanoclastic that find between these layers was the geological evidence that some-how the volcanoclastic had flown and buried the Layer B below $430 \mathrm{~cm}$ of sediment before Layer A was formed. Based on the microscopy description of rock samples, layer B below $430 \mathrm{~cm}$ of sediment before Layer A was formed. Based on the microscopy description of rock samples, layer B formed in shallow lacustrine transitions with oxicepilimnion condition, over-grown by grass like vegetation which adaptive in water saturated-soil which classify as histosol-spodosol. The soil was formed from coarsens volcanoclastic that exposed and weathered by oxygen-rich atmospheric hydrological dynamic. Accumulation of organic matter was intense in this area, which deposits in this soil. It indicated that caldera was flooded in the sequence of time by atmospheric precipitation rain.

Layer A had more finely grain and also had less content of organic matter. There is not much of the iron oxide and organic matter that shown there are soil formed in oxic conditions or fertile as Layer B. It seems that Layer A was anoxic and less fertile. Weathered biotite minerals \& its fragments are more dominant along within the lamination of the pedoplasmation. There are several presences of mudcrack patterns that commonly found in the soil with clay grain size. It's shown that in this sequence of time, layer A was formed in the anoxic hypolimnionunfertile swampy environment which no much oxygen that involves in soil-forming.

The changing of conditional of the depositional environment might relate to the dynamic of the structural geological deformation of Toba Caldera Complex. Samosir Island was the manifestation of Toba Caldera floor uplifts, as the consequence of NWSE Samosir fault activity that occurs along at eastern of the island (Chesner, 2012; de Silva, et al, 2015). Along with that, it might also relate to the dynamic of lacustrine hydrological of Toba Caldera that can be flooded along the lacustrine-backwash zone. To reconfirm this event there are need several further comprehensive research.

\section{Conclusion}

Based on the interpretation of the paleosoil layer that has observed in microscopy observation, at least there are two events of soil-forming that separated by the volcanoclastic flow in the past time. The older paleosoil layer was a soil that formed from weathered coarser volcanoclastic which deposited in the transition of lacustrine with oxic epilimnion. The younger paleosoil was a layer of soil that forms from volcanic ash that deposited in anoxic hypolimnion which exposed to arid atmospheric the generally form mud-crack pattern. It indicated that the soil-forming process in Samosir Island at the pastime was parallel with island uplift and the flooded moment of Toba Caldera.

\section{Acknowledments}

The present research is was supported by Hibah Peneltiian Smart Mandiri Institut Teknologi Sumatera 2017. Furthermore, acknowledgment is also expressed for partial support for all expertise assistance and technical contributions to the research activity.

\section{References}

Aldiss, D.T., Ghazali, S.A., 1984. The regional geology and evolution of the Toba volcano-tectonic depression, Indonesia. J. Geol. Soc. London. 141, 487-500. https://doi.org/10.1144/gsjgs.141.3.0487

Chesner, C.A., 2012. The Toba Caldera Complex. Quat. Int. 258, 5-18. https://doi.org/10.1016/j.quaint.2011.09.025

Dahlgren, R., Shoji, S., \& Nanzyo, M., 1993. Mineralogical characteristics of volcanic ash soils. Dev. Soil Sci. 21, 101-143. https://doi.org/https://doi.org/10.1016/S01662481(08)70266-6

de Silva, S. L., Mucek, A. E., Gregg, P. M., \& Pratomo, I., 2015. Resurgent Toba-Field, chronologic, and model constraints on time scales and mechanisms of resurgence at large calderas. Front. Earth Sci. 3. https://doi.org/https://doi.org/10.1016/S01662481(08)70266-6

Driese, S.G., Peppe, D.J., Beverly, E.J., DiPietro, L.M., Arellano, L.N., Lehmann, T., 2016. Paleosols and paleoenvironments of the early Miocene deposits near Karungu, Lake Victoria, Kenya. Palaeogeogr. Palaeoclimatol. Palaeoecol. 443, 167-182.

https://doi.org/10.1016/j.palaeo.2015.11.030

Hoosbeek, M.R., Bryant, R.B., 1992. Towards the quantitative modeling of pedogenesis - a review. Geoderma 55, 183-210. https://doi.org/10.1016/0016-7061(92)90083-J

Imbellon, P.A., 2011. Classification of paleosols. Geociências, 30, 05-13.

Laliberté, E., Grace, J.B., Huston, M.A., Lambers, H., Teste, F.P., Turner, B.L., Wardle, D.A., 2013. How does pedogenesis drive plant diversity? Trends Ecol. Evol. 28, 331-340. https://doi.org/10.1016/j.tree.2013.02.008 
Mack, G.H., James, W.C., Monger, H.C., 1993. Stoops, G., \& Schaefer, C.E., 2018. Pedoplasmation: Classification of paleosols. Geol. Soc. Am. Bull. 105, 129-136. https://doi.org/10.1130/00167606(1993)105<0129:COP>2.3.CO;2

Nemecz, E., \& Csikós-Hartyáni, Z., 1995. Processes in soils and paleosoils. GeoJournal 36, 1390142. https://doi.org/https://doi.org/10.1007/BF00813 158

Nettleton, W.D., Olson, C.G., Wysocki, D.A., 2001. Erratum: Paleosol classification: Problems and solutions (Catena (2000) 41 (61-92) PII: S0341816200001090). Catena 43, 161. https://doi.org/10.1016/S0341-8162(00)00159-4

Ninkovich, D., Shackleton, N. J., Abdel-Monem, A. A. Obradovich, J. D., \& Izett, G., 1978. K-Ar age of the late Pleistocene eruption of Toba, north Sumatra. Nature 276, 574-577. https://doi.org/https://doi.org/10.1038/276574a 0 formation of soil material. In Interpretation of micromorphological features of soils and regoliths. Elsevier 59-71. https://doi.org/https://doi.org/10.1016 /B978-0444-63522-8.00004-8

Tabor, N.J., Myers, T.S., 2015. Paleosols as indicators of paleoenvironment and paleoclimate. Annu. Rev. Earth Planet. Sci. 43, 333-361. https://doi.org/10.1146/annurev-earth-060614105355

Timmreck, C., Graf, H. F., Zanchettin, D., Hagemann, S., Kleinen, T., \& Krüger, K., 2012. Climate response to the Toba super-eruption: Regional changes. Quat. Int. 258, 30-44. https://doi.org/https://doi.org/10.1016/j.quaint.2 011.10.008

Ugolini, F.C., Dahlgren, R.A., 2002. Soil development in volcanic ash. Glob. Environ. Res. 6, 69-81.

Solada, K., 2018. Resurgent uplift of Samosir Island in Toba Caldera, Indonesia: Insights from Lake Sediment Paleomagnetism and P14P C Age Determination. Oregon State Univ.

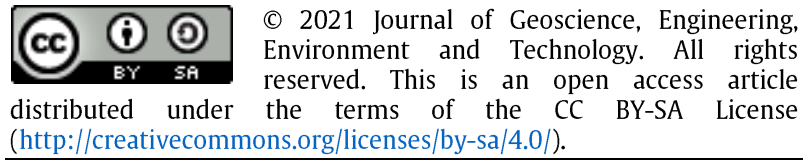

